\author{
St ud i a P ilosophic a \\ Wrat i s l a vi e n s i a \\ vol. XV, fasc. $2(2020)$ \\ https://doi.org/10.19195/1895-8001.15.2.12
}

\author{
ANNA JEDYNAK \\ ORCID: 0000-0002-1893-8289 \\ Uniwersytet Warszawski
}

\title{
O zmienności granic nauki
}

\section{On the Changeability of Science's Limits}

\begin{abstract}
The limits of science change primarily as a result of new discoveries. But there can be other reasons, of a conceptual and/or methodological nature. The essence and structure of science can be understood differently, which results in different definitions of its limits. The text discusses some areas in which the limits of science were defined differently. Firstly, on the grounds of logical empiricism, views distant from direct experience, as generalisations and theories, have been excluded from science, narrowing its limits. Secondly, the lack of an unshakable and strictly empirical basis has been found within the limits of science, while previously that basis was thought necessary. Thus, the limits of science were again found narrowed. Thirdly, previously neglected and rather unwanted evaluative elements have been repeatedly discovered at the base of science. It was claimed to sanction them within the limits of science. In that case the latter per se would not change their range, however their concept would have to broaden. Last but not least, for various and not necessarily intentional reasons, the limits of science has become vague.
\end{abstract}

Keywords: decidability, ethics, limits of science, observation, theory, values

\section{Wprowadzenie}

Zmienność granic nauki wydaje się sprawą oczywistą. Natychmiast nasuwa nam się jej powód: nowe odkrycia, zmiana treści teorii naukowych. Obalono pewne stare prawa, sformułowano nowe - granice nauki się przesunęły. Rozwój nauki 
nie jest jednak jedynym powodem zmiany jej granic, choć zapewne jest powodem najlepiej dostrzegalnym. Najwięcej mogliby o nim powiedzieć sami badacze, toteż będzie tu pominięty.

Ale są jeszcze inne powody. Tylko ten pierwszy, wspomniany wyżej, ma charakter realny: zmieniają się granice nauki, bo zmieniło się coś w praktyce badawczej, niezależnie od ludzkich przekonań o nauce. Pozostałe powody natomiast zakorzenione są w naszych o niej przekonaniach i mają charakter pojęciowy. Granice nauki „zmieniają się” nie tylko wraz z jej realnymi przekształceniami, lecz także wraz ze zmianą naszej wizji tych granic czy woli ich wytyczenia.

Wytyczanie to być może związane albo z takim czy innym pojmowaniem samej istoty nauki i ma wtedy wymiar metodologiczny, albo też może być bardziej marginalne - chodzi po prostu o umowne zaostrzenie dla porządku pewnych nieostrych granic, związane z doprecyzowaniem znaczenia jakichś wyrażeń, lecz nie idą z tym w parze kwestie metodologiczne.

Zacznijmy od tych drobniejszych spraw. Wyrażenie ,granice nauki” używane bywa w różnych znaczeniach, zależnie między innymi od kontekstu dyskursu. Czy wyznacznikiem granic nauki ma być raczej sam jej dorobek, czy także niezależne od niego działanie badawcze? Czy w granicach tych mają się mieścić kwestie faktycznie rozstrzygnięte, czy także te, do których rozstrzygnięcia nauka racjonalnie zmierza?

Przypuszczalnie pierwszym znaczeniem nieco bardziej jesteśmy skłonni kierować się w wypadku nauk stosowanych, tam gdzie interesują nas przede wszystkim wdrożenia. Na przykład możemy nie chcieć przyznać, że w granicach nauki leży obecnie lekarstwo gwarantujące wyleczalność choroby Parkinsona, nawet jeśli się nad takowym pracuje, bo nikomu jeszcze zaaplikować go nie można. Obejmą je być może przyszłe granice nauki. Natomiast drugie znaczenie nabiera wagi w wypadku nauki czystej (dla której możliwości wdrożeń mogą ujawnić się później), ograniczonej raczej do teoretycznej spekulacji i wstępnych prób powiązania jej z ludzkimi potrzebami. Łatwiej niż w wypadku lekarstwa na chorobę Parkinsona zgodzimy się, że w granicach nauki leży integracja mechaniki kwantowej z teorią względności. A do tej zgody wystarczy nam, że nauka zajmuje się tym zagadnieniem, i nie ma powodu, by z góry wykluczać możliwość uzasadnionego rozwiązania.

Zatem o tym, czy granice nauki mierzyć jej rezultatami, czy realistycznymi dążeniami, decydować miałby w jakimś stopniu kontekst, wyznaczony naszymi oczekiwaniami: czy chodzi nam zdecydowanie o praktyczny pożytek, czy — przynajmniej na razie - o satysfakcję intelektualną, której dostarczają nawet małe kroki?

Granice nauki mierzone jej dorobkiem wydają się ostrzejsze niż te mierzone jej możliwościami. Wśród problemów nierozstrzygniętych istnieje gradacja: najbliższe rozstrzygnięcia są te w toku testów; dalej te, dla których procedury testujące są bardzo zaawansowane, choć jeszcze niewdrażane; jeszcze dalej — te rozstrzygalne zasadniczo, którym jednak daleko do rozstrzygalności technicznej (notabene samo przechodzenie rozstrzygalności zasadniczej danej hipotezy w jej rozstrzygalność techniczną to nie jest jednorazowy krok, lecz proces); wreszcie takie, których roz- 
strzygalność zasadniczą nauka dopiero rozważa i próbuje — ze skutkiem niewiadomym ex ante — nadać im taki kształt, aby im jac zapewnić. Wszystko to pozostawia wielorakie możliwości określania granic nauki.

Dochodzi do tego jeszcze jedno pytanie: czy granice nauki mają obejmować jedynie problemy, jakie nauka rozstrzygnęła bądź ma uzasadnione nadzieje rozstrzygnąć, czy także szereg czynności/procedur/technik służebnych temu celowi? Czy leży w jej granicach całe jej zaplecze, wszelkie środki uzyskiwania odpowiedzi?

Na użytek dalszych rozważań umówmy się pojmować granice nauki możliwie najobszerniej ze względu na przedstawione dystynkcje. Zauważmy jednak, że powyższe kwestie można podejmować, względnie przesądzać, nie kłopocząc się o to, czym naprawdę nauka jest. Gdy jednak uwzględnimy, że różne są poglądy metodologiczne na istotę i strukturę nauki, dostaniemy kolejne powody zmienności jej granic. Wraz ze zmianami poglądów metodologicznych fluktuacjom podlega samo pojęcie nauki i naukowości, a w konsekwencji — pojęcie granic nauki oraz tych granic wytyczenie.

W filozofii nowożytnej i współczesnej można wyróżnić trzy kierunki metodologicznej rewizji dobrze uprzednio zakorzenionych poglądów na granice nauki:

1. Wyłączano z nauki pewne elementy tradycyjnie do niej zaliczane i zawężano tym sposobem jej granice. Dotyczyło to przede wszystkim górnych pięter gmachu nauki empirycznej, raczej odległych od bezpośredniej bazy doświadczalnej.

2. Stwierdzano w granicach nauki niewystępowanie pewnych elementów, uważanych wcześniej za niezbywalne dla niej. A dotyczyło to, paradoksalnie, właśnie owego obserwacyjnego fundamentu, który miał być stabilny i niewzruszony. To, w czym go upatrywano, okazało się mieć nieco inną naturę. W tym wypadku także granice nauki miały okazać się węższe, niż sądzono wcześniej.

3. Odkrywano w nauce pewne elementy, uprzednio ignorowane i raczej w niej niepożądane, lecz po ujawnieniu uznane za przydatne czy wręcz niezbywalne. Dotyczyło to (czy raczej — dotyczy, bo sprawa jest nadal żywa) obszaru wartości i ich związków z nauką. Upominano się o usankcjonowanie ich miejsca w granicach nauki. Granice te nie miały obejmować niczego ponad to, co już wcześniej w nich się mieściło, miały jednak być poszerzone w stosunku do wcześniejszych na ich temat przekonań.

4. Z różnych przyczyn, przede wszystkim związanych z praktycznym uprawianiem nauki oraz z konfrontacją refleksji metodologicznej z praktyką, postępuje stałe rozmywanie granic nauki.

Tylko punkt pierwszy zmierzał do rewizji czy też modyfikacji praktyki naukowej, czego konsekwencją miało być węższe zakreślenie granic nauki (a czy zamierzenie to się powiodło, to już inna sprawa). Dwa kolejne miały raczej korygować poglądy na granice nauki bez faktycznej ich zmiany, poprzez trafniejsze rozpoznanie tego, co się w ich obrębie znajduje. Ostatni stanowi nie do końca zamierzoną konsekwencję rozwoju praktycznych procedur, instytucjonalnego funkcjonowania nauki oraz prób aplikacji poglądów metodologicznych do praktyki naukowej.

Przyjrzyjmy się teraz poszczególnych zabiegom i procesom składającym się na wymienione sposoby rewizji granic nauki. 


\section{Wyłączanie z nauki zdań odległych od bezpośredniego doświadczenia}

Punkt pierwszy znakomicie ilustrowany jest historią empiryzmu ${ }^{1}$. Przypomnijmy: wczesny, genetyczny empiryzm brytyjski miał się pierwotnie za sukcesora kartezjańskiego ideału wiedzy powszechnej i niepodważalnej. Podtrzymując go, widział $\mathrm{w}$ granicach nauki miejsce dla praw empirycznej proweniencji. Dopiero Hume ujawnił niemożność poznania, które z jednej strony byłoby ogólne i pewne, a z drugiej - wywiedzione z empirii. Walor prawomocnego uzasadnienia przyznał jedynie ogólnej apriorycznej wiedzy pojęciowej oraz wiedzy o faktach jednostkowych. Odmówił go ogólnej wiedzy o faktach, choć rozumiał i akceptował ludzkie oczekiwania i działania, ukształtowane z przyczyn praktycznych tak, jak gdyby kierowane były ogólnymi prawami empirycznymi, lecz w istocie oparte, jego zdaniem, na nawyku².

Kant z kolei rehabilitował amputowane przez Hume'a „czyste przyrodoznawstwo", wychodząc nie od pryncypiów, lecz od faktycznie praktykowanej ówcześnie nauki. Granice nauki znów są u niego szersze, wyznaczone przez to, co miał za realia, nie zaś przez refleksję nieliczącą się z realiami ${ }^{3}$.

Spór o granice nauki ożywił się znacznie w minionym stuleciu. Odżyły idee Hume'a. Wpływ na to miały gwałtowne przeobrażenia w fizyce, nieoczekiwane odwoływanie dobrze zakorzenionych teorii, uznawanych za nieodparcie dowiedzione, rewolucja relatywistyczna i kwantowa. Myśl neopozytywistów, spadkobierców Hume'a, szła w następującym kierunku: skoro prawa nauki skazane zostały na odwołanie, nie były to w istocie prawa rzetelnej nauki, lecz jakiejś quasi-nauki, do której przedostały się nieuprawnione wtręty metafizyczne. Granice rzetelnej nauki należy przeto zakreślić węziej, niż to $\mathrm{w}$ praktyce dotychczas czyniono, i dopiero taka nauka rozwijać się będzie kumulatywnie, bez żenujących „wypadków przy pracy”.

W ich rozumowaniu tkwił podstawowy błąd, zbyt rzadko im wytykany: skoro głównym wyróżnikiem metafizyki miała być w ich oczach niesprawdzalność i brak związków z empirią, jakim sposobem właśnie wtręty metafizyczne miałyby ponosić odpowiedzialność za kolizję teorii naukowych z doświadczeniem, a w konsekwencji za konieczność ich odwołania? Niemniej jednak pozytywiści rozwinęli i upowszechnili próby określania czy modyfikowania granic nauki pod wpływem refleksji metodologicznej.

Jeśli naukę empiryczną pojmować, jak to się czasem tradycyjnie czyni, na kształt gmachu, którego podstawę stanowią fakty, dalej idą ich opisy jednostkowe, uogólnienia tych opisów, prawa ogólne o wzajemnych zależnościach faktów i wreszcie teorie, to pozytywiści uszczuplali ten gmach od góry niezmiernie drastycznie, w szczególności we wczesnym okresie swojej działalności. Propozycje mieli rozma-

${ }^{1}$ Zob. Dziedzictwo logicznego empiryzmu, M. Czarnocka (red.), Warszawa 1995; A. Jedynak, Empiryzm i znaczenie, Warszawa 1998.

2 D. Hume, Traktat o naturze ludzkiej, tłum. C. Znamierowski, Warszawa 2005 [wyd. oryg. 1738]; D. Hume, Badania dotyczace rozumu ludzkiego, tłum. J. Łukasiewicz, K. Twardowski, Kraków 1947 [wyd. org. 1748].

${ }^{3}$ I. Kant, Krytyka czystego rozumu, tłum. M. Żelazny, Toruń 2013 [wyd. oryg. 1781]. 
ite, bo okazało się, że metafizyczna „niesprawdzalność” nie jest pojęciem jasnym i eksplikowana może być różnie.

Pod neopozytywistyczny nóż poszły nie tylko uogólnienia (jako nie w pełni dowodliwe doświadczalnie) i teorie (jako nieprzekładalne na zdania obserwacyjne), lecz także zdania bliższe „dołu” wspomnianego gmachu: kwestionowana była niepodważalność zdań protokolarnych wyrażonych w języku innym niż fenomenalistyczny — a wszak nauka miała mieć zapewnioną niepodważalność.

Jednak neopozytywistyczne propozycje nie cieszyły się szczególną stabilnością ani powszechnym uznaniem. Z dwóch powodów: po pierwsze, usunęły z nauki zbyt wiele, prezentując jej model niezgodny z przyjętą praktyką i potrzebami wdrożeniowymi. Takie okrawanie nauki było wszelako zgodne z intencjami filozofów, którzy je przeprowadzali. Po drugie, ich pomysły obfitowały w rozliczne niepożądane konsekwencje. Typowy był następujący scenariusz: przyjmowano jakieś ustalenie ogólne, które miało wyeliminować z nauki określony typ zdań, po czym okazywało się, że w myśl tegoż ustalenia wypadają z nauki także inne zdania, których ustalenie owo, zgodnie z intencją twórców, wcale objąć nie miało!

Dochodziły i inne trudności techniczne: neopozytywiści próbowali osobno zdefiniować sensowność naukową dla zdań (miała przysługiwać zdaniom sprawdzalnym), a osobno dla terminów (miała przysługiwać terminom definiowalnym za pomocą terminów obserwacyjnych). Spodziewali się przy tym, że wszystkie zdania zbudowane są z terminów sensownych i tylko one będą spełniać kryteria sensowności przewidzianej dla zdań - ale tu się pomyli. Mogą istnieć zarówno zdania w ich pojęciu sensowne, do których ,zaplątały się” wyrażenia bezsensowne, jak i zdania bezsensowne (czyli niesprawdzalne), zbudowane wyłącznie z terminów w ich pojęciu sensownych. Jeszcze inne kłopoty dotyczyły prób odpowiedzi na pytanie o status empirycznego kryterium sensu, które według krytyków nie spełniało samo siebie.

Wszystkie te trudności powodowały stopniową liberalizację programu empiryzmu logicznego. Na przykład własną główną tezę zaczął on uznawać nie za deskryptywną, lecz za preskryptywną, zalecającą określoną praktykę naukową, a pełna sprawdzalność jako wymóg naukowości zastąpiona została najpierw potwierdzalnością, a z czasem przydatnością heurystyczną. Takie podejście widać niekiedy również w Szkole Lwowsko-Warszawskiej, która ostrożnie i w ograniczonym stopniu inspirowała się niektórymi ideami empiryzmu logicznego ${ }^{4}$.

Podobny charakter ma falsyfikacjonizm Poppera. Z falsyfikowalności uczynił Popper wyróżnik naukowości, relegując poza granice nauki zdania niefalsyfikowalne $^{5}$. Jednak ani neopozytywiści, ani Popper nie zdołali zreformować praktyki naukowej (choć wpływ Poppera jest z pewnością znaczniejszy). Praktycy nie kierowali się zaleceniami filozofów głoszących, jak naukę uprawiać i jakiego typu zdania w niej formułować. Na przykład niefalsyfikowalna psychoanaliza ma się nieźle, nie mówiąc o tym, że realizacja wczesnych postulatów neopozytywistów okroiłaby

${ }^{4}$ I. Dąmbska, Irracjonalizm a poznanie naukowe, „Kwartalnik Filozoficzny” 14 (1937), s. 83-118; M. Kokoszyńska-Lutmanowa, W sprawie walki z metafizyka, „Przegląd Filozoficzny” 41 (1938), s. 9-24; J. Kotarbińska, Z zagadnień teorii nauki i teorii języka, Warszawa 1990.

${ }^{5}$ K.R. Popper, Logika odkrycia naukowego, tłum. U. Niklas, Warszawa 1977 [wyd. oryg. 1959]. 
naukę ponad wszelką dopuszczalną miarę. Gdyby zaś kierować się wizją holistycznego uprawiania nauki, trzeba by uznać za falsyfikowalne jedynie całościowe teorie (a w skrajnym wypadku — naukę jako całość), odmówić natomiast falsyfikowalności i naukowości poszczególnym prawom wyjętym z szerszego kontekstu.

Krótko mówiąc, ujawnienie niedodeterminowania empirycznego praw nauki zaowocowało próbą zawężenia jej granic, ale nie można powiedzieć, aby próba ta się powiodła.

\section{Wątpliwości co do empirycznych podstaw nauki}

Refleksja metodologiczna ujawniła w nauce pewne istotne niedostatki, wskazując, że nie ma w jej granicach tego, co — jak sądzono — do niej należy.

Ujawnienie pierwszego braku jest dobrze znane. Miały się nauki przyrodnicze wspierać na niewzruszonym, empirycznym fundamencie poznania, który okazał się fikcją ze względu na teoretyczne skażenie obserwacji ${ }^{6}$. Zdania uważane za obserwacyjne i służące potwierdzaniu teorii formułowane są zawsze w kontekście uprzednich założeń teoretycznych. Brakuje więc nauce tego, co uważano za jej niezależną od teorii podstawę. Rzekoma podstawa okazuje się fikcją, nie leży zatem w granicach nauki. Metaforę gmachu wspartego solidnie na podłożu zastępuje metafora domu na palach, wznoszącego się ponad ziemią. Teoria, pozbawiona wsparcia w niezależnej od niej obserwacji, wydaje się mieć obniżony stopień uzasadnienia. Mniej solidnie są granice nauki ufortyfikowane i bardziej rozmyte. Zarazem majaczy nad nauką widmo błędnego koła ze względu na wzajemne relacje teorii i obserwacji, skutkujące ostatecznie zarzuceniem tej dychotomii.

Ujawnienie drugiego braku jest dziełem polskiego filozofa ze Szkoły Lwowsko-Warszawskiej, a sam wynik nie upowszechnił się w filozofii nauki. Kazimierz Ajdukiewicz uznał, że metoda bezpośredniego doświadczenia, leżąca u podstaw nauk empirycznych, nie spełnia wymogów naukowości ${ }^{7}$. Zgodnie ze standardami tej Szkoły racjonalność (niezbędna dla naukowości) ma za warunek komunikowalność i intersubiektywną sprawdzalność. Otóż, zdaniem Ajdukiewicza, bezpośrednie doświadczenie nie jest intersubiektywnie sprawdzalne. Nawet ta sama osoba nie może powtórzyć i przeżyć powtórnie tego samego doświadczenia, lecz co najwyżej zaaranżować inne doświadczenie tego samego typu lub polegać na własnej pamięci. Bezpośrednie doświadczenie jest subiektywne i niepowtarzalne. Wymogiem nauki zaś jest obiektywność i sprawdzalność oparta na powtarzalności. Naukowość zaczynać się ma wraz z uogólnieniami (konkluzja z gruntu przeciwna wnioskom neopozytywistów). Punkt wyjścia nauki, zaliczany zwykle do niej, leży więc poza jej granicami.

Trzeci brak wiąże się z zainicjowanym przez konwencjonalizm podważeniem fundamentalizmu poznawczego, zakwestionowaniem rudymentarnych poglądów na naturę wiedzy przyrodniczej, ujawnieniem roli umysłu w poznaniu oraz so-

\footnotetext{
${ }^{6}$ Ibidem.

${ }^{7}$ K. Ajdukiewicz, Subiektywność $i$ niepowtarzalność metody bezpośredniego doświadczenia, [w:] idem, Język i poznanie, t. 2, Warszawa 1985 [1 wyd. 1962].
} 
cjo- i psychologicznych uwarunkowań rozwoju nauki ${ }^{8}$. Zdania pozornie empiryczne uznano bądź za konwencje, wyposażające terminy nauki w znaczenie i niestanowiące rezultatu rozstrzygnięć empirycznych, lecz będące warunkiem ich przeprowadzenia, bądź za zdania o komponentach mieszanych, często nieodróżnialnych. O konwencjach zaś przesądzają decyzje, a nie nauka. Nie leżą one tedy w granicach rozstrzygnięć naukowych, nawet jeśli na naukę wpływają.

Czwarty brak dotyczy nauk dedukcyjnych i związany jest z twierdzeniami limitacyjnymi ${ }^{9}$. Z istotnych względów nie leżą w granicach nauki rozstrzygnięcia pewnych problemów na gruncie wystarczająco bogatych systemów dedukcyjnych. I znów — nie jest to werdykt absolutny, lecz relatywny, zależny od przyjętej aksjomatyki. Toteż granice nauki wymykają się jednoznacznemu ustaleniu: z jednej strony nie ma problemu, który nie dałby się rozstrzygnąć przy odpowiednio bogatych środkach dowodowych, a z drugiej - nie ma obejmującego arytmetykę systemu aksjomatycznego, który rozstrzygałby wszystkie dające się sformułować na jego gruncie problemy. Którędy zatem biegną te granice?

\section{Wartościujące aspekty nauki}

Kolejna rewizja granic nauki idzie w całkowicie przeciwnym kierunku niż propozycje neopozytywistów. Ujawniane są mianowicie wartościujące aspekty nauki. Nie chodzi przy tym o antynaturalistycznie pojmowane pewne dyscypliny humanistyczne, których zadaniem jest na przykład ocena dzieł kultury, lecz o gros nauk, z uwzględnieniem tych empirycznych. Czyni się to na dwa sposoby. W wersji łagodniejszej, nienaruszającej Hume'owskiego paradygmatu, w myśl którego powinności nie wynikają z samych faktów, stwierdza się istotne podobieństwa lub powiązania między nauką a aksjologią. W szczególności wartości mają rządzić wdrożeniami i być niezbędne naukom stosowanym. W wersji mocniejszej upatruje się wartości w samym rdzeniu nauki, zasypując podział między nimi a faktami i biorac rozbrat z Hume'em.

Wątek powiązań między nauką a aksjologią podejmowany był w szczególności przez filozofów ze Szkoły Lwowsko-Warszawskiej, którzy antycypowali idee przedstawiane w filozofii zachodniej kilka dekad później. Kazimierz Ajdukiewicz, a potem Marian Przełęcki (uważany czasem za reprezentanta drugiego pokolenia Szkoły) wskazywali na podobieństwo między bezpośrednim, sensualnym poznaniem jakości zmysłowych rzeczy a również bezpośrednim, lecz intuicyjnym poznaniem wartości ${ }^{10}$. Pierwsze owocuje zdaniami opisowymi, uogólnianymi następnie do praw empirycznych, a drugie zdaniami oceniającymi, uogólnianymi do zasad etycznych. Wskazywali też wiele innych, dokładniejszych analogii, lecz nie było ich

${ }^{8}$ A. Siemianowski, Zasady konwencjonalistycznej filozofii nauki, Warszawa 1989.

${ }^{9} \mathrm{~S}$. Krajewski, Twierdzenie Gödla i jego interpretacje filozoficzne. Od mechanicyzmu do postmodernizmu, Warszawa 2003.

${ }^{10}$ K. Ajdukiewicz K., Postępowanie człowieka, [w:] idem, Jęzk i poznanie, t. 2, s. 317-364 [1 wyd. 1938]; M. Przełęcki, Poza granicami nauki. Z semantyki poznania pozanaukowego, Warszawa 1996; M. Przełęcki, Sens i prawda w etyce, Warszawa 2004. 
zamiarem poszerzanie granic nauki o poznanie aksjologiczne. Wszelako w świetle ich wywodów naukowość okazuje się sprawą nie tyle jakościową, ile raczej ilościową. A sama granica przestaje jawić się jako przepaść, bardziej przypominając nakreśloną na ziemi linię.

Natomiast w ujęciu Tadeusza Czeżowskiego poznanie wartości, z etyką na czele, sytuuje się w granicach nauk empirycznych. Nie sprowadził on przy tym wartości do cech ani do relacji rzeczy, wystrzegając się tym samym naturalizmu, i nie sprowadził ich do ludzkich postaw, wystrzegając się subiektywizmu. Uznał je za sposoby, w jakie cechy czy relacje rzeczom przysługuja, obiektywnie nadbudowane nad empirią i od niej zależne, choć pozbawione empirycznej treści. Koncepcja ta stanowiła próbę obejścia ograniczeń nałożonych na poznanie aksjologiczne przez Hume'a i poszerzenia tym samym granic nauki.

Kazimierz Twardowski, twórca Szkoły Lwowsko-Warszawskiej, na wiele sposobów podnosił kwestię naukowości etyki, różnie — mocniej lub słabiej — tę naukowość pojmując. Jak się okaże, jedynie najmocniejsza, ale i najbardziej kontrowersyjna jego propozycja zbliżona jest do dzisiejszych prób aksjologizacji nauki. W sensie najsłabszym ,naukowe” to u niego tyle co racjonalne, odwołujace się do rozsądnych argumentów i wolne od dogmatów. W tym najsłabszym sensie kwalifikował Twardowski jako naukową tradycyjną etykę, podejmującą klasyczne problemy ${ }^{11}$. (Notabene Popper zarezerwował osobny obszar dla problemów racjonalnych, choć nienaukowych ${ }^{12}$. Pojmował racjonalność słabiej od naukowości i tak też my dziś jesteśmy skłonni czynić. Racjonalność argumentacji etycznej nie dowodzi w naszym odczuciu jej naukowości).

Nieco mocniej pojmował Twardowski naukowość etyki, zestawiając ją z dyscyplinami stosowanymi, jak higiena, pedagogika czy logika ${ }^{13}$. Nauka stosowana formułuje zależności przyczynowo-skutkowe natury empirycznej, testowalne, wskazujące, jakie poczynania zapewniają realizację przyjętych celów. Cele wniesione są do niej z zewnątrz, ale gdy już zostaną przyjęte, nauka podaje gotowe recepty ich realizacji. I tak medycyna nastawiona jest na zachowanie zdrowia i zwalczanie chorób, pedagogika na określone rezultaty wychowawcze, logika na poprawność wnioskowań - nauki te wskazują, jak te cele osiągać. Podobnie miałaby postępować etyka - jej celem jest dobre moralnie postępowanie, a jej treścią opis, jak postępować, aby zachować moralność. Formułuje ona normy, ale nie różni się w tym od higieny czy pedagogiki. Dlatego nie godzi się, zdaniem Twardowskiego, odsądzać etykę od naukowości z racji jej normatywności. Ciekawe, że do jednego z przykładów użytych przez Twardowskiego sięgnął po latach w podobnym celu John R. Searle ${ }^{14}$. Przykład dotyczył logiki i obaj myśliciele zauważyli, że występu-

${ }^{11}$ K. Twardowski, O sceptycyzmie etycznym. Wyktadów z etyki część II, „Etyka” 9 (1971), s. 173222 [1 wyd. 1905-1906].

${ }^{12}$ K.R. Popper, Mit schematu pojęciowego. W obronie nauki i racjonalności, tłum. B. Chwedeńczuk, Warszawa 1997.

${ }^{13}$ K. Twardowski, Gtówne kierunki etyki naukowej. Wykładów z etyki część I, „Etyka” 13 (1974), s. 196-226 [1 wyd. 1905-1906].

14 J.R. Searle, Czynności mowy. Rozważania z filozofii języka, tłum. B. Chwedeńczuk, Warszawa 1987 , s. $169-172$. 
je w niej wartościujące określenie wnioskowania poprawnego, pozwalające logice formułować normy.

W omawianym modelu Twardowskiego istotne jest, że cele, którym ma służyć nauka, nie leżą w jej granicach i że dopiero pozanaukowa, aksjologiczna domieszka pozwala na formułowanie norm. Wskutek tego model jest zgodny z tradycją Hume'owską. Próbował jednak Twardowski na różne sposoby znieść niesamodzielność aksjologiczną nauki (do czego jeszcze wrócimy).

Uderza podobieństwo opisanej propozycji Twardowskiego do późniejszej redukcji przyczynowej Quine'a ${ }^{15}$. Ta ostatnia koncepcja miała w pewnej mierze poprawić niekorzystną sytuację metodologiczną etyki w stosunku do nauk szczegółowych. W miejsce sporów o wartości zaproponował Quine — dopóty, dopóki chodziłoby o wartości nie autoteliczne, lecz instrumentalne, służące realizacji innych, nadrzędnych wartości — formułowanie zależności przyczynowych, wskazujących, jakie środki gwarantują osiąganie przyjętych celów. Ma zatem etyka odkrywać prawa empiryczne, głoszące, w jaki sposób, kierując się wartościami instrumentalnymi, realizować wartości autoteliczne lub przynajmniej inne wartości instrumentalne, bliższe w porządku przyczynowym wartościom autotelicznym.

Uzasadnieniem wartości instrumentalnych ma być ich przydatność (bezpośrednia lub pośrednia) w realizacji wartości autotelicznych. Zależności te mają charakter empiryczny (jak u Twardowskiego) i są testowalne. Byłaby to próba częściowej naturalizacji etyki. Częściowej — gdyż kończyłaby się tam, gdzie rzecz zaczęłaby tyczyć celów najwyższych i wartości autotelicznych. Tych nie ma już do czego redukować i nie można im zapewnić empirycznego uzasadnienia. Ale też co do nich, zdaniem Quine'a, jest między ludźmi najmniej kontrowersji. Etyka zostałaby w jakiejś mierze odciążona z jałowych sporów, sięgając do faktów tam, gdzie mogą być jej przydatne, lecz nie wkraczając w granice nauki.

U Twardowskiego i u Quine'a logiczna rekonstrukcja jest taka sama, lecz inne jest rozmieszczenie akcentów. Uderza odmienność konkluzji, jakimi obaj myśliciele opatrzyli swoje, jakże podobne, pomysły. Twardowski zdaje się sądzić, że przedstawił etykę jako naukę, podczas gdy Quine nadal słusznie dostrzega różnice i odrębność etyki. Zdaje się, że Quine trafniej od Twardowskiego ocenił metodologiczny status tak zrekonstruowanej etyki. Tym niemniej poczynił Twardowski krok w kierunku dopuszczenia w granicach nauki miejsca na problematykę wartości.

Ale nie było to jeszcze jego ostatnie słowo w kwestii naukowości etyki. Twardowski uznał, że można uniezależnić naukę od wniesionego z zewnątrz elementu wartościującego ${ }^{16}$. Próbował wykazać to na różne sposoby, z czego na szczególną uwagę zasługuje jeden i przy nim się zatrzymamy. Przyjął na wstępie, że czyny moralnie dobre to te, które minimalizują konflikty między ludźmi, a etyka ma pracować nad sformułowaniem empirycznie testowalnego kryterium wskazującego, jakie konkretnie czyny będą taki właśnie skutek odnosić. Mamy tu jawnie natura-

15 W.V.O. Quine, Granice wiedzy i inne eseje filozoficzne, tłum. B. Stanosz, Warszawa 1986, s. 163-175 [wyd. oryg. 1978].

${ }^{16} \mathrm{~K}$. Twardowski, O zadaniach etyki naukowej. Wykładów z etyki część III, „Etyka” 13 (1973), s. 123-155 [1 wyd. 1905-1906]. 
listyczne założenie, definiujacce czyny moralnie dobre na podstawie ich cech oderwanych od relacji empirycznych. Definicja ta przyjęta jest jako pewna niewarta refleksji metodologicznej oczywistość i na niej oparty jest ciąg dalszy. Ów niewypowiedziany explicite naturalizm cofa Twardowskiego przed Hume'a i tym sposobem pozwala uniknąć ograniczeń nałożonych przez Hume'a na normatywność. Nie wspomniał jednak Twardowski, że tym samym bierze rozbrat z Hume'em, co jednak jest faktem. Nie podnosił różnic między dwoma zaproponowanymi przez siebie modelami.

Drugi z nich znajduje dzisiejszy odpowiednik w poglądach Sama Harrisa, amerykańskiego neurobiologa i filozofa. Również u niego widać podejście naturalistyczne - za dobre uważa on to, co służy dobrostanowi, rozpoznawanemu na podstawie empirycznych faktów. Przy czym Harris jawnie kwestionuje Hume'owskie rozgraniczenie powinności i faktów i ma je za wielki błąd ${ }^{17}$. Argumentuje podobnie jak Twardowski, powołując się na analogię etyki do innych nauk, na przykład medycyny. Skutek jednak jest dalej idący, gdyż chodzi mu nie tylko o naukowe uprawianie etyki (choć od tej wizji nie stroni), lecz także o ujawnienie aksjologicznych podstaw całej nauki w ogóle. Ma naukę za nieodłączną od problematyki wartości, które jego zdaniem tkwią u samych źródeł nauki i stanowią warunek jej rozwoju.

Nie jest tak, twierdzi Harris, że do nauki, aby mogła być wdrażana, wnoszone są z zewnątrz wartości, cele i ogólne normy, dyskusyjna zaś byłaby natura związków nauki z jej aksjologicznym pograniczem. Nie jest to bowiem żadne pogranicze, lecz rdzeń i punkt wyjścia nauki. Bez wartości nie byłoby dążeń, a bez dążeń nie byłoby badań. Nadto wartości te tkwią immanentnie w samych strukturach myślenia. Są to na przykład zaufanie do świadectw, standardy dowodzenia, niesprzeczność logiczna, pasja poznawcza, dążenie do zrozumienia świata czy do dobrostanu. Są one tak oczywiste, że nie pytamy o ich uzasadnienie. I słusznie, bo nie uzasadni ich żadna nauka. Nie można dowieść standardów dowodzenia ani przywołać świadectw na rzec ufności w świadectwa. Można szukać potwierdzenia tych wartości w skuteczności nauki, ale już sama kategoria skuteczności wskazuje na przyjęty cel. Samo zamierzenie badawcze jest już nośnikiem i wyrazem wartości.

Opozycję Harrisa wobec Hume'a może stosowniej byłoby wyrazić nie krótkim zdaniem: powinności wynikają z faktów, lecz w obszerniejszej, złagodzonej formie: powinność wynika z faktów ujętych w wartościujących strukturach myślenia, nieodłącznych od tego myślenia. Podobne poglądy głoszą w środowisku amerykańskim także inni filozofowie, chętnie sięgający, jak Harris, do świadectw neuronalnych dotyczących różnych stanów świadomości i procesów poznawczych ${ }^{18}$.

17 S. Harris, Pejzaż moralny. W jaki sposób nauka może określać wartości, tłum. P.J. Szwajcer, Stare Groszki 2012.

18 A. Edel, Ethical Judgment. The Use of Science in Ethics, Glencoe 1955; A. Edel, Science and the Structure of Ethics, Chicago 1961; O. Flanagan, The Really Hard Problem. Meaning in a Material World, Cambridge 2007; W.D. Casebeer, Natural Ethical Facts. Evolution, Connectionism, and Moral Cognition, Cambridge 2003; M. Shermer, The Moral Arc. How Science and Reason Lead Humanity toward Truth, Justice, and Freedom, Nowy Jork 2015; idem, The Science of Good and Evil. Why People Cheat, Gossip, Care, Share, and Follow the Golden Rule, New York 2004. 


\section{Rozmywanie granic nauki}

Wymienione zostały, po pierwsze, te elementy nauki, które uznano za niegodne obywatelstwa w niej, po drugie — te, co do których odkryto, że nigdy ich w nauce nie było. O te obie grupy próbowano zawężać koncepcje granic nauki, mniej lub bardziej skutecznie. Po trzecie zaś - te elementy, których dopatrzono się w obrębie nauki i których obecność tam niektórzy uznali (wbrew rozpowszechnionym przekonaniom) za wskazaną czy wręcz niezbędną. Podejmowane są próby, aby o te elementy granice nauki poszerzać. Ale oprócz prób zawężania czy poszerzania granice nauki spotkała jeszcze jedna zmiana, a mianowicie ich rozmywanie. $\mathrm{Na}$ to ostatnie złożyło się wiele przyczyn, często niemających nic wspólnego z refleksją metodologiczną.

Po pierwsze, niezbyt realne było definitywne usunięcie z nauki wszelkich elementów, którym odmówiono prawa obywatelstwa w niej. I nie chodzi tu nawet o rozdźwięk między teoretykami a praktykami. Sami teoretycy widzieli, że nie mogą nadmiernie zubożyć nauki. Elementy niezbyt chętnie przez nich w nauce widziane, lecz trudne do usunięcia delegowali tedy na jakieś obrzeża nauki, gdzie miałyby odgrywać rolę pomocniczą czy podrzędną. I tak na przykład zdezawuowane przez neopozytywistów prawa ogólne miały mieć status reguł inferencji. Niedodeterminowanym teoriom można było odmówić roli eksplanacyjnej, pozostawiając im jedynie rolę instrumentalną. Na obrzeżach, niejako w drugiej linii, postawiono kiedyś wyrażenia teoretyczne przydatne heurystycznie, choć niedefiniowalne za pomocą terminów obserwacyjnych. Kwestie niefalsyfikowalne, lecz w jakiś sposób istotne delegować można za Popperem w obszar nienaukowy, ale racjonalny.

Podział na pierwszą i drugą linię nauki, na jej bardziej i mniej istotne części, przeniknął do różnych koncepcji w rozmaitej szacie słownej i z różną eksplikacją. Na przykład mamy u Kuhna paradygmat i rozstrzygane na jego gruncie w okresach nauki normalnej pomniejsze problemy ${ }^{19}$; mamy u Lakatosa twardy rdzeń i pas ochronny $^{20}$.

Wreszcie do niezbędnych obrzeży zaliczają się źródła nauki, uznawane niekiedy za nienaukowe. Należą do nich w ujęciu Ajdukiewicza jednostkowe, subiektywne i niepowtarzalne świadectwa empiryczne oraz przez tegoż filozofa podniesione przedmioty intensywnej pracy myślowej, przekuwającej swobodne intuicje w systemy aksjomatyczne ${ }^{21}$. Należą też do nich hipotezy, dla których jeszcze nie opracowano procedur testujących, ale jest szansa na uczynienie tego w przyszłości. Gdyby hipotezy te z góry zarzucić jako nietestowalne i z tego powodu niegodne zainteresowania uczonych, nigdy nie doczekałyby się tych procedur. Wydaje się, że praca badawcza to w jakiejś części praca w niebudzących wątpliwości granicach

19 T.S. Kuhn, Struktura rewolucji naukowych, tłum. S. Amsterdamski, Warszawa 1968.

${ }^{20}$ I. Lakatos, Pisma z filozofii nauk empirycznych, tłum. W. Sady, Warszawa 1995.

21 „Zanim myśl nasza osiągnie ten stopień precyzji, który pozwala na wyraźne sformułowanie aksjomatów, ma się już jakoś daną tę koncepcję [...] daną w sposób mętny i niewyraźny. Aby się z tych mętów wydobyć, potrzeba poważnego wysiłku myślowego. [...] Można jej [tej pracy] nie nazywać robotac naukową, nie można jej jednak odmówić wartości dla naukowego poznania" - K. Ajdukiewicz, O tzw. Neopozytywizmie, [w:] idem, Język i poznanie, t. 2, s. 28 [1 wyd. 1946]. 
nauki, ale w innej części — praca przy zakwalifikowaniu do nauki czegoś, co jeszcze do niej nie należy.

Na rozmycie granic wpływa też zarzucenie ostrego podziału na prawa uzasadnione i pozbawione uzasadnienia (z ewentualną perspektywą nabycia go później). Świadcząca o naukowości rozstrzygalność zależy od możliwości uzasadnienia. Uzasadnienie zaś jest sprawą stopnia, i to zarówno w modelu indukcjonistycznym, jak i w hipotetyczno-dedukcyjnym. W pierwszym modelu zależy ono od bazy obserwacyjnej, a ta jest stopniowalna. W drugim od hipotez wymaga się spełnienia licznych warunków, które spełnione mogą być w różnym stopniu. Na przykład ma być hipoteza mało prawdopodobna a priori, ma mieć szeroki zakres zastosowań, pozytywne świadectwa, zróżnicowane jakościowo i mało prawdopodobne bez uwzględnienia danej hipotezy. Wszystko to jest sprawą stopnia. Nadto niektóre z tych cech zmieniają się w czasie i w miarę postępu badań mogą przysługiwać hipotezie w coraz wyższym stopniu, a zatem coraz bardziej przydawać jej naukowości. Dawniej procedury badawcze były mniej zaawansowane i szybciej trwała ich realizacja. Teraz następuje rozciągnięcie w czasie skomplikowanych programów pracy zespołowej - dlatego lepiej widać stopniowe nabywanie przez hipotezy mocy predykcyjnej, świadczącej o ich naukowości.

Amerykański filozof Abraham Edel, optujący za naukowością etyki, zauważył stopniowalność standardów naukowości w zależności od dyscypliny oraz sukcesywne osłabianie i rozmywanie tych standardów w miarę rozwoju nauki i filozofii nauki — zupełnie przeciwnie do pierwotnych zamysłów neopozytywistów, którzy chcieli te standardy wzmocnić i uściślić ${ }^{22}$.

Wreszcie, mamy wieloraki pluralizm scjentystyczny, mnogość systemów teoretycznych, wyjściowych założeń, obszarów zastosowań, paradygmatów, a także niekompatybilność teorii, stosowanych z powodzeniem w odmiennych obszarach. Po przełomie antypozytywistycznym rolę umysłu w poznaniu naukowym widzimy jako znaczniejszą niż widziano ją dawniej. Rola ta wypełnia w strukturze nauki lukę, jaką ujawniło empiryczne niedodeterminowanie praw. A jako że łatwiej uczonemu zmienić perspektywę poznawczą, zmienić sposób ujęcia materiału doświadczalnego przez umysł czy przez język, niż zmienić fakty, o których mniema, że determinuja kształt teorii - tedy mamy jeszcze jeden powód, dla którego granice dawnej nauki, rzekomo wyznaczonej ściśle przez fakty, jawiły się jako sztywniejsze od obecnych.

Podważenie fundamentalizmu epistemologicznego skutkowało zatem potrzebą uwzględniania różnych odniesień i większą pokorą epistemologiczną. Przeniknęła ona także do języka: mniej mówi się o prawdzie, za to więcej o racjonalności przekonań; mniej o nieodpartym uzasadnieniu, a więcej o uzasadnieniu komparatywnym, względnym lub wystarczająco wysokim.

Natomiast pojęcie granic nauki na razie jeszcze nie doczekało się wyrażenia zastępczego. Być może dlatego, że refleksja teoretyków nie idzie w parze z praktyką i potrzebami społecznymi. O ile refleksja odkrywa rozmycie granic nauki, o tyle praktyka domaga się od nauki pewności lub prawie pewności. Pewność zaś wymaga

${ }^{22}$ A. Edel, Ethics — A Modest Science?, „Zygon: Journal of Religion \& Science” 15 [1] (1980), s. $7-19$. 
granic wyraźnych, a nie rozmytych. Rośnie nasz standard życia i rośnie zapotrzebowanie na jego dalszy wzrost. Zwłaszcza wrażliwi jesteśmy na unikanie zagrożeń i na zapewnienie sobie w dzisiejszym nieprzewidywalnym świecie bezpieczeństwa. Skutkuje to obwarowywaniem wdrożeń osiągnięć nauki licznymi barierami. Ile testów muszą pozytywnie przejść na przykład nowe lekarstwa czy udogodnienia komunikacyjne, zanim uzyskają zgodę na rozpowszechnienie! I jak bardzo zminimalizowane być musi wszelkie ryzyko ich zastosowania! Dawniejsze podejście nie było tak rygorystyczne.

O ile jednak dzisiejsze wymogi wzrosły, o tyle realizacja odstaje od nich w sposób niekiedy kompromitujący dla instytucjonalnej nauki. Daleko posunięta komercjalizacja, niejasne związki z biznesem, presja na szybkie osiąganie i upublicznianie rezultatów pracy badawczej, krótko kwitowana określeniem publish or perish, oraz korupcja niejednokrotnie skutkują nadużyciami, prowadzącymi nawet do fałszowania wyników i prób tuszowania fałszerstw ${ }^{23}$. Powstaje zatem rozbieżność między granicami nauki wyznaczonymi sprawozdawczo przez to, czym się ona faktycznie zajmuje i co zalicza do swego dorobku, a jej granicami określonymi normatywnie ze względu na przyjęte standardy jej uprawiania i na tradycyjny etos naukowca.

\section{Bibliografia}

Ajdukiewicz K., O tzw. Neopozytywizmie, [w:] idem, Język i poznanie, t. 2, Warszawa 1985 , s. $7-28$.

Ajdukiewicz K., Postępowanie człowieka, [w:] idem, Język i poznanie, t. 2, Warszawa 1985, s. 317-364.

Ajdukiewicz K., Subiektywność i niepowtarzalność metody bezpośredniego doświadczenia, [w:] idem, Język i poznanie, t. 2, Warszawa 1985, s. 371-373.

Casebeer W.D., Natural Ethical Facts. Evolution, Connectionism, and Moral Cognition, Cambridge 2003.

Czeżowski T., Pisma z etyki i teorii wartości, Wrocław 1989.

Czarnocka M. (red.), Dziedzictwo logicznego empiryzmu, Warszawa 1995.

Dąmbska I., Irracjonalizm a poznanie naukowe, „Kwartalnik Filozoficzny” 14 (1937), s. $83-118$.

Edel A., Ethical Judgment. The Use of Science in Ethics, Glencoe 1955.

Edel A., Science and the Structure of Ethics, Chicago 1961.

Edel A., Ethics - A Modest Science?, „Zygon: Journal of Religion \& Science” 15 [1] (1980), s. $7-19$.

Goldman A.J., Kim J. (eds.), Values and Morals, Dordrecht 1978.

Harris S., Pejzaż moralny. W jaki sposób nauka może określać wartości, tłum.

P.J. Szwajcer, Stare Groszki 2012.

Hume D., Traktat o naturze ludzkiej, tłum. C. Znamierowski, Warszawa 2005.

${ }^{23}$ Zob. np. S. Krimsky, Nauka skorumpowana? O niejasnych zwiazkach nauki $i$ biznesu, tłum. B. Biały, Warszawa 2006; oraz Fraud proven in papers of former CNRS president Anne Peyroche, https://forbetterscience.com/2018/10/09/fraud-found-in-papers-of-former-cnrs-president-annepeyroche/ (dostęp: 16.10.2018). 
Hume D., Badania dotyczace rozumu ludzkiego, tłum. J. Łukasiewicz, K. Twardowski, Kraków 1947.

Flanagan O., The Really Hard Problem. Meaning in a Material World, Cambridge 2007.

Fraud proven in papers of former CNRS president Anne Peyroche, https://forbetterscience.com/2018/10/09/fraud-found-in-papers-of-former-cnrs-president-anne-peyroche/ (dostęp: 16.10.2018).

Jedynak A., Empiryzm i znaczenie, Warszawa 1998.

Kant I., Krytyka czystego rozumu, tłum. M. Żelazny, Toruń 2013.

Kokoszyńska-Lutmanowa M., W sprawie walki z metafizyka, „Przegląd Filozoficzny” 41 (1938), s. 9-24.

Kotarbińska J., Z zagadnień teorii nauki i teorii języka, Warszawa 1990.

Krajewski S., Twierdzenie Gödla i jego interpretacje filozoficzne. Od mechanicyzmu do postmodernizmu, Warszawa 2003.

Krimsky S., Nauka skorumpowana? O niejasnych zwiazkach nauki i biznesu, tłum. B. Biały, Warszawa 2006.

Kuhn T.S., Struktura rewolucji naukowych, tłum. S. Amsterdamski, Warszawa 1968.

Lakatos I., Pisma z filozofii nauk empirycznych, tłum. W. Sady, Warszawa 1995.

Popper K.R., Logika odkrycia naukowego, tłum. U. Niklas, Warszawa 1977.

Popper K.R., Mit schematu pojęciowego, [w:] idem, Mit schematu pojęciowego. W obronie nauki i racjonalności, tłum. B. Chwedeńczuk, Warszawa 1997, s. 41-75.

Przełęcki M., Poza granicami nauki. Z semantyki poznania pozanaukowego, Warszawa 1996.

Przełęcki M., Sens i prawda w etyce, Warszawa 2004.

Quine W.V.O., O naturze wartości moralnych, [w:] idem, Granice wiedzy i inne eseje filozoficzne, tłum. B. Stanosz, Warszawa 1986, s. 163-174.

Searle J.R., Czynności mowy. Rozważania z filozofii języka, tłum. B. Chwedeńczuk, Warszawa 1987.

Shermer M., The Moral Arc. How Science and Reason Lead Humanity toward Truth, Justice, and Freedom, New York 2015.

Shermer M., The Science of Good and Evil. Why People Cheat, Gossip, Care, Share, and Follow the Golden Rule, New York 2004.

Siemianowski A., Zasady konwencjonalistycznej filozofii nauki, Warszawa 1989.

Twardowski K., Główne kierunki etyki naukowej. Wyktadów z etyki część I, „Etyka” 13 (1974), s. 196-226.

Twardowski K., O sceptycyzmie etycznym. Wykładów z etyki część II, „Etyka” 9 (1971), s. $173-222$.

Twardowski K., O zadaniach etyki naukowej. Wykładów z etyki część III, „Etyka” 12 (1973), s. 123-155. 